\title{
FACTORS AFFECTING ADHERENCE TO ANTIRETROVIRAL THERAPY: APPLICATION OF THEORY OF PLANNED BEHAVIOR IN MALANG, EAST JAVA
}

\author{
Fitria Diyah Ayu Pangerti'), Pawito²), Hanung Prasetya3) \\ 1)Masters Program in Public Health, Universitas Sebelas Maret \\ 2)Faculty of Social and Political Sciences, Universitas Sebelas Maret \\ ${ }^{3)}$ Health Polytechnics Ministry of Health Surakarta
}

\begin{abstract}
Background: Adherence to antiretroviral (ARV) treatment is known as an important component in achieving the success of an optimal HIV therapy program. Poor adherence to antiretroviral therapy (ART) is associated with less effective viral suppression, which creating permanent treatment resistance. The purpose of this study was to examine factors affecting adherence to ARV therapy.

Subjects and Method: A cross-sectional study was conducted in Malang, East Java, from September to October 2019. A sample of 200 PLWH was selected by fixed disease sampling. The dependent variable was adherence to ARV therapy. The independent variables were cues to action, perceived susceptibility, perceived benefit, attitude, and CST service. The data were collected by medical record and questionnaire. The data were analyzed by a multiple linear regression.

Results: Adherence to ARV therapy in PLWH increased with strong cues to action (OR= 6.40; $95 \% \mathrm{CI}=3.13$ to 13.12 ; $\mathrm{p}<0.001)$, strong perceived susceptibility (OR=3.61; 95\% $\mathrm{CI}=$ 1.82 to $7.13 ; \mathrm{p}<0.001)$, strong perceived benefit $(\mathrm{OR}=4.68 ; 95 \% \mathrm{CI}=2.37$ to 9.28 ; $\mathrm{p}<0.001)$, and positive attitude $(\mathrm{OR}=5.39 ; 95 \% \mathrm{CI}=2.69$ to $10.83 ; \mathrm{p}<0.001)$. CST service was associated with adherence to ARV therapy but it was statistically non-significant (OR= 0.63 ; $95 \% \mathrm{CI}=0.33$ to $1.20 ; \mathrm{p}=0.130$ ).

Conclusion: Adherence to ARV therapy in PLWH increases with strong cues to action, strong perceived susceptibility, strong perceived benefit, and positive attitude. CST

Keywords: Care, support, and treatment service, people living with HIV/AIDS

\section{Correspondence:}

Fitria Diyah Ayu Pangerti. Masters Program in Public Health, Universitas Sebelas Maret. Jl. Ir. Sutami 36A, Surakarta 57126, Central Java, Indonesia. Email: ayupangerti13@yahoo.com. Mobile: 081332600710.
\end{abstract}

The $7^{\text {th }}$ International Conference on Public Health

Solo, Indonesia, November 18-19, $2020 \mid 164$ https://doi.org/10.26911/the7thicph.02.53 